\title{
EQUILIBRIUM STATE OF JAKOBSHAVNS ISBRA, WEST GREENLAND
}

\author{
by
}

M.S. Pelto, T.J. Hughes,

(Department of Geological Sciences and Institute for Quaternary Studies, University of Maine, Orono, ME 04469 , U.S.A.)

and

\section{H.H. Brecher}

(Institute of Polar Studies, The Ohio State University, Columbus, OH 43210, U.S.A.)

\section{ABSTRACT}

Jakobshavns Isbræ, located at $69^{\circ} 10^{\prime} \mathrm{N}$ on the west coast of Greenland, is the world's fastest known glacier. Measurement of surface velocities at the calving front in July of 1964, 1976, 1978, 1985, and 1986 yielded a mean velocity of $20.6 \mathrm{~m} / \mathrm{d}$. Variation in mean velocity from year to year is less than $1 \mathrm{~m} / \mathrm{d}$. Velocity measurements $10 \mathrm{~km}$ behind the calving front indicated mean annual velocities of $17.1 \mathrm{~m} / \mathrm{d}$ compared to mid-summer velocities of $17.6 \mathrm{~m} / \mathrm{d}$. The maximum possible decline in winter velocity is then $7 \%$. Calculation of the volume flux into the fjord is $3.72 \times 10^{10} \mathrm{~m}^{3} \mathrm{a}^{-1} \pm 10 \%$. The surface balance of Jakobshavns Isbræ is $3.37 \times 10^{10} \mathrm{~m}^{3} \mathrm{a}^{-1} \pm 12 \%$. The agreement between these balance calculations, the long-term stability in glacier velocity, and the reasonably stable glacier front indicate that Jakobshavns Isbræ is in a state of near equilibrium, with probably a small negative balance.

\section{INTRODUCTION}

Jakobshavns Isbræ is located on the west coast of Greenland at $69^{\circ} 10^{\prime} \mathrm{N}$ (Fig. 1). Jakobshavns Isbræ is fed by two ice streams, one extending up to $100 \mathrm{~km}$ into the Greenland ice sheet, and it drains between 4.0 and $5.8 \%$ of the Greenland ice sheet (Fig. 1). The lower $10 \mathrm{~km}$ of the glacier is afloat in Jakobshavn Isf jord. The $7.2 \mathrm{~km}$ wide calving front discharges between 5.0 and $6.0 \%$ of the annual net balance of the Greenland ice sheet.

Jakobshavns Isbræ has the fastest persistent velocity of any known glacier. Velocity measurements conducted at the glacier front in July of 1964 (Carbonnell and Bauer, 1968), 1976 (Lingle and others, 1981), 1978, 1985, and 1986, and $12 \mathrm{~km}$ back from the glacier front in 1978, 1985, and 1986 , gave a unique data set for observation of ice-stream dynamics over a period of 22 years. This paper is the first analysis of the data collected by the University of Maine in 1978, 1985, and 1986, that are being used to generate orthophoto maps of Jakobshavns Isbræ. The final goal is a detailed stress-strain-rate analysis of this ice stream. The object of this paper is to determine the mass balance of Jakobshavns Isbræ.

\section{VELOCITY MEASUREMENT}

In this section, the methods used in four different periods of velocity monitoring are discussed. In 1964, in conjuction with the Expedition Glaciologique Internationale au Groenland, Carbonnell and Bauer (1968) used aerial photogrammetric tracking of salient seracs and crevasses to calculate velocities for a transect at the calving front and for a transect $3 \mathrm{~km}$ behind the calving front (Fig. 2). The aerial photography was flown at an altitude of $4000 \mathrm{~m}$ on

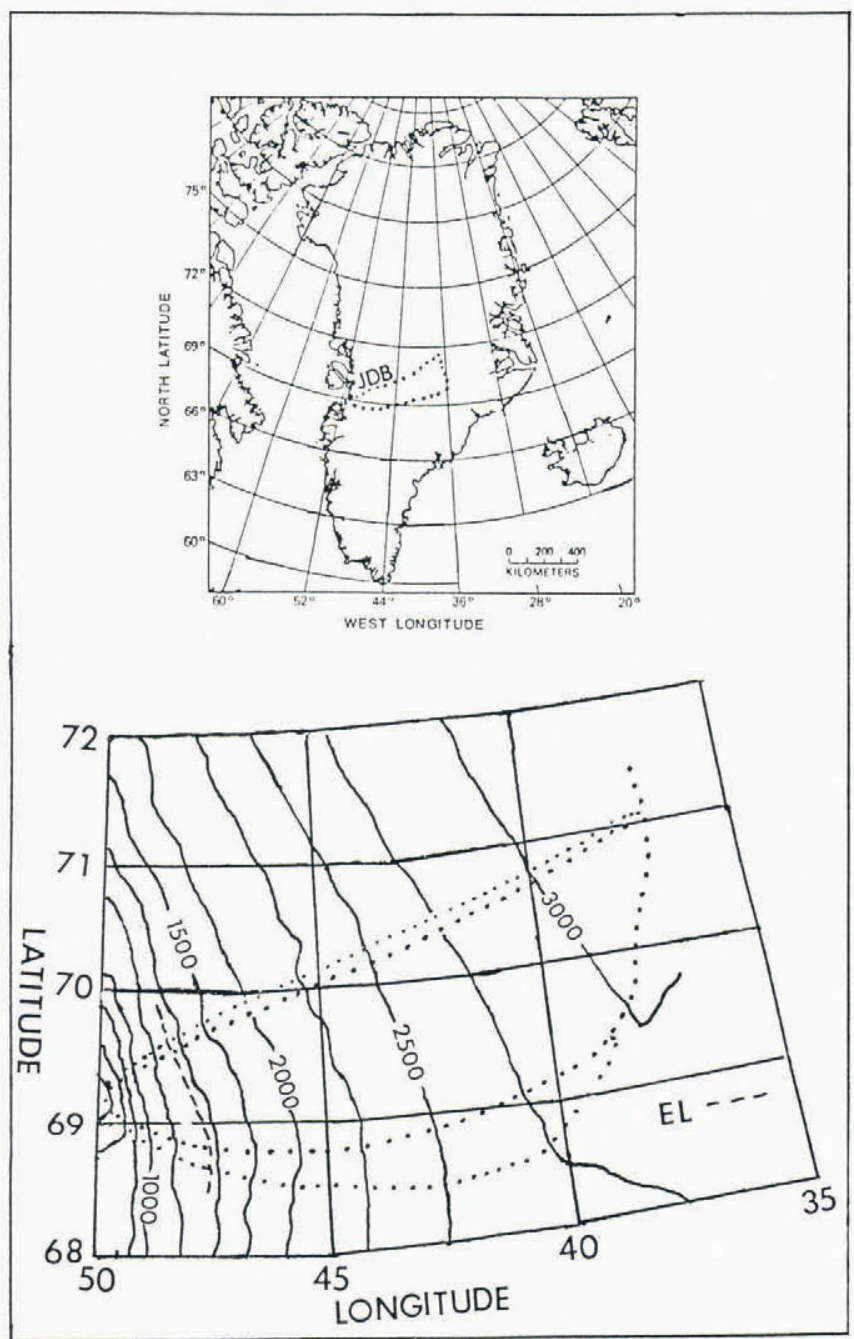

Fig. 1. Map of the drainage-basin area of Jakobshavns Isbræ, minimum and maximum drainage-basin boundaries indicated by (...), and elevation contoured at $250 \mathrm{~m}$ intervals.

29 June and 12 July. The accuracy of the velocity data is $\pm 1.0 \%$ (Carbonnell and Bauer, 1968). The errors in velocity determination are small with respect to the magnitude of the velocity vector. An error of $1.0 \%$ for a $13 \mathrm{~d}$ period, in which salient-feature movements were $250 \mathrm{~m}$, is $2.5 \mathrm{~m}$. 


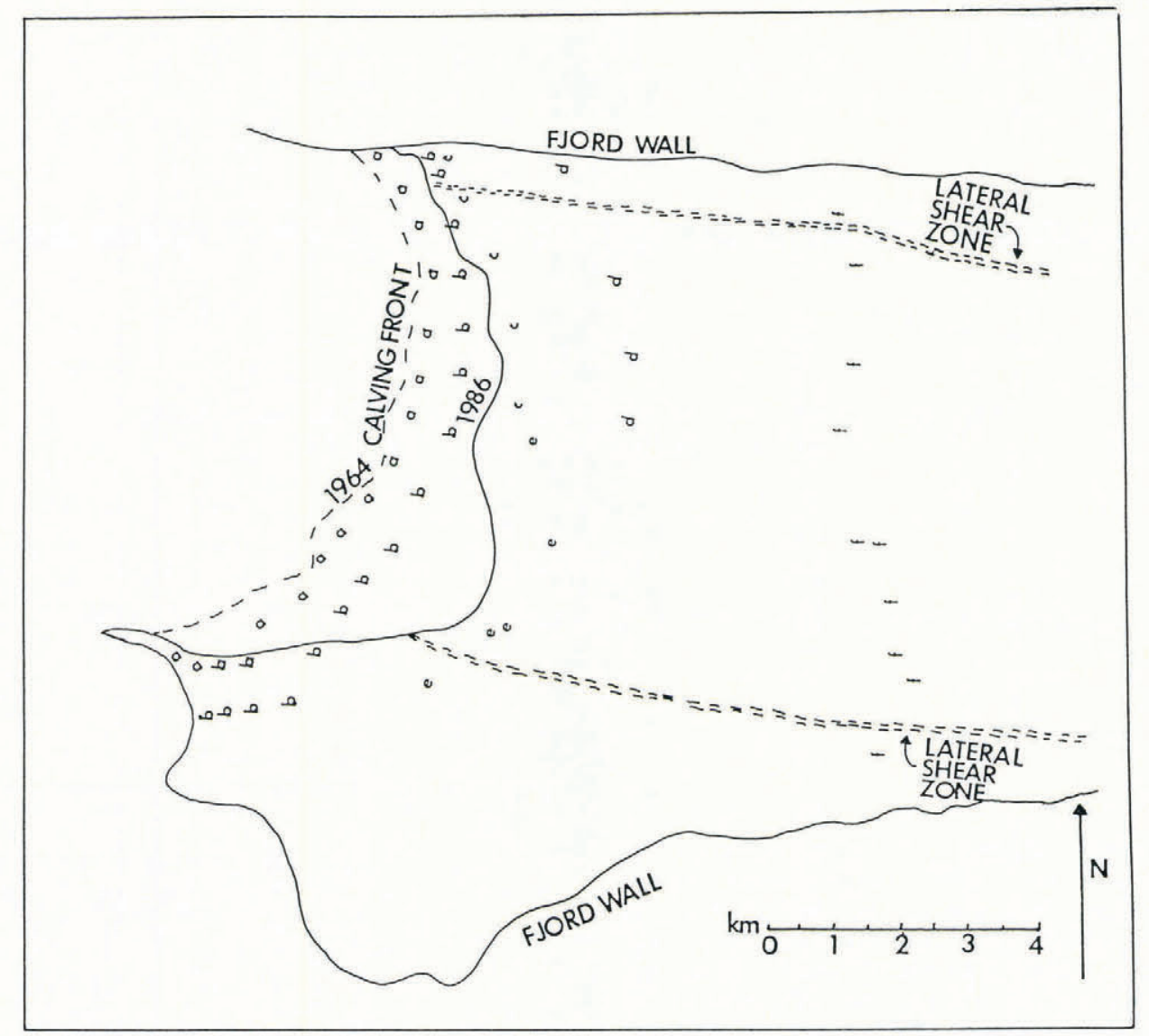

Fig. 2. Map of the fjord region of Jakobshavns Isbra, indicating the 1964 terminus position (- - -) and the 1986 terminus position (-). Locations of velocity-measurement sites are indicated by individual letters; each transect is denoted by a group of the same letter. Transect a, the calving front in 1964. Transect $\mathrm{b}, 1.5 \mathrm{~km}$ behind the calving front in 1964. Transect $\mathrm{c}$, the calving front in 1976. Transect d, $3 \mathrm{~km}$ behind the calving front in 1976. Transect e, calving front in 1978. Transect $\mathrm{f}, 8 \mathrm{~km}$ behind the calving front in 1978 .

In July of 1976 and 1978, the University of Maine tracked prominent seracs on the lower part of Jakobshavns Isbræ. The seracs, marked by dye dropped from a helicopter, were surveyed from ground-based stations (Lingle and others, 1981). Transects at the calving front and $3 \mathrm{~km}$ behind the calving front were monitored during a 3 week period in July (Fig. 2). In 1978, an additional transect was completed $10 \mathrm{~km}$ back from the calving front. The accuracy of the ground-based triangulation surveys was $\pm 2 \%$ (Lingle and others, 1981).

In July of 1985 and 1986, the University of Maine conducted two aerial photogrammetric survey missions at a 3 week interval on the lower $12 \mathrm{~km}$ of Jakobshavns Isbræ. Transects of glacier velocity were determined at the calving front 3,5 , and $8-12 \mathrm{~km}$ behind the calving front (Fig. 3). The photographs were taken from an altitude of $9500 \mathrm{~m}$. The resolution of the photographs allows identification of $2 \mathrm{~m}$ by $2 \mathrm{~m}$ objects. Glacier velocities were calculated for 3 week periods based on the movement of selected seracs and crevasses. Dimensional position of these features was determined by using conventional aerial block triangulation (Brecher, 1986). The surveyed points on the glacier were referenced to control points on either bedrock wall. The resulting velocity vectors have an accuracy of $\pm 1 \%$ within the observed velocity range of $5-22 \mathrm{~m} / \mathrm{d}$.

The velocity $8-12 \mathrm{~km}$ behind the calving front was determined for the July 1985 to July 1986 period. The movement of $8 \mathrm{~m}$ black targets (Griffolyn T-55 target material anchored with cobbles) was noted in photographic missions in July 1985 and again in July 1986. The measurements identified the annual velocity in the zone $9-12 \mathrm{~km}$ behind the calving front. Errors in velocity determination were $\pm 0.1 \%$ for the observed range of movements of $4000-7000 \mathrm{~m}$.

Table I documents the mean velocity observed on each transect during the 5 years in which measurements were completed. The lower $10 \mathrm{~km}$ of Jakobshavns Isbræ is afloat and there is negligible vertical velocity or transverse velocity. The velocity vectors on the lower part of the glacier are all one-dimensional and parallel to each other, except in a few locations in the marginal zones. The annual velocity $10 \mathrm{~km}$ behind the calving front in the central part of the glacier is $17.1 \mathrm{~m} / \mathrm{d}$ in comparison with $17.6 \mathrm{~m} / \mathrm{d}$ for the mid-summer velocity. This indicates that the maximimum decrease in velocity during the winter is $7 \%$. The variation in velocity in a tranverse profile divides the glacier into two distinct zones. The central zone has a width of $6000 \mathrm{~m}$ and velocities are uniform. The marginal parts of the glacier adjacent to both fjord walls are $2600 \mathrm{~m}$ wide. The marginal zones are separated from the central part of the glacier by clearly visible lateral shear zones (Figs 2 and 3 ). Velocities decrease sharply across the lateral shear zones of the glacier. Because of the wide variation in velocity in the marginal zone of the glacier, it is not yet possible to determine the actual mean velocity. Upper and lower limits of the mean velocity in the marginal zones are 9 and $12.5 \mathrm{~m} / \mathrm{d}$.

\section{VOLUME FLUX}

The small variation in velocity from year to year on Jakobshavns Isbræ allows calculation of a long-term volume flux. Annual volume flux $(V)$ is calculated using Equation (1) where $u$ is velocity, $w$ is glacier width, and $h$ is ice thickness

$$
V=u w h .
$$

For calculating the volume flux $10 \mathrm{~km}$ behind the calving front, the glacier width and mean glacier velocity are known. The only unknown is glacier thickness. It is 


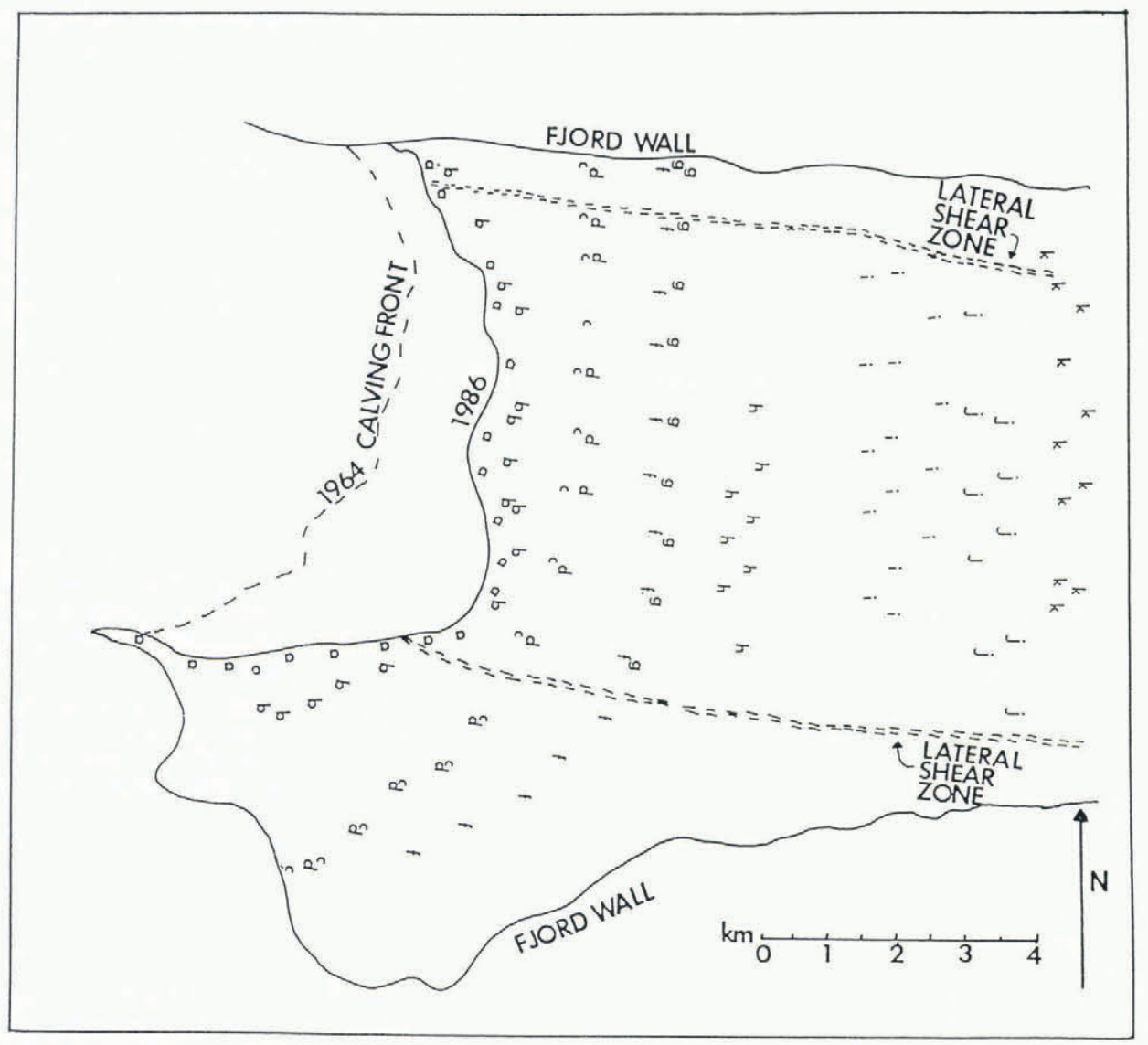

Fig. 3. Map of the fjord region of Jakobshavns Isbræ, indicating the 1964 terminus position (- - -) and the 1986 terminus position (-). Locations of velocity-measurement sites are indicated by individual letters; each transect is denoted by a group of the same letter. Transect a, calving front in 1985. Transect b, calving front in 1986. Transect c, $1.5 \mathrm{~km}$ behind the calving front in 1985. Transect d, $1.5 \mathrm{~km}$ behind calving front in 1986. Transect $\mathrm{f}, 3 \mathrm{~km}$ behind calving front in 1985. Transect $\mathrm{g}, 3 \mathrm{~km}$ behind calving front in 1986. Transect h, $5 \mathrm{~km}$ behind calving front in 1986 . Transect i, $6 \mathrm{~km}$ behind the calving front in 1985. Transect j, $8 \mathrm{~km}$ behind the calving front during the July 1985 to July 1986 period. Transect k, $9 \mathrm{~km}$ behind calving front in 1985 . Transect $1,9 \mathrm{~km}$ behind the calving front from July 1985 to July 1986.

TABLE I. MEAN GLACIER VELOCITY ALONG TRANSECTS IN THE CENTRAL ZONE OF JAKOBSHAVNS ISBRÆ, IN $\mathrm{m} / \mathrm{d}$. FIGURES 2 AND 3 IDENTIFY THE LOCATIONS OF THE VARIOUS GLACIER-VELOCITY TRANSECTS

$\begin{array}{lcccccc}\text { Year } & 1964 & 1976 & 1978 & 1985 & 1986 & 1985-86 \\ & & & & & & \\ \text { Velocity at glacier front } & 21.1 & 20.4 & 21.0 & 20.6 & 20.3 & - \\ \text { Velocity 3 km behind glacier front } & 19.6 & 19.1 & - & 19.0 & 19.4 & - \\ \text { Velocity 10 km behind glacier front } & - & - & 17.6 & 17.8 & 17.5 & 17.1\end{array}$

apparent from the disappearance of tidal flexure that the glacier grounds between 9 and $12 \mathrm{~km}$ behind the calving front. The surface altitude of the glacier at the point where it is known to be completely afloat, $8 \mathrm{~km}$ behind the calving front, is used to calculate ice thickness based on the buoyancy requirement of ice. As the ice thickness above sea-level is $75-82 \mathrm{~m}$ at the glacier center, the thickness is between 750 and $825 \mathrm{~m}$.

Minimum and maximum volume fluxes are calculated. The minimum volume flux uses the minimum ice-thickness estimate and the minimum estimate for velocity in the marginal zone of the glacier. The volume flux is calculated separately for the central and marginal zones, and the resulting fluxes are summed for the total glacier flux.

Table II indicates the values used in calculating the volume flux $10 \mathrm{~km}$ behind the calving front. The minimum flux is $3.43 \times 10^{10} \mathrm{~m}^{3} \mathrm{a}^{-1}$ and the maximum flux is $4.01 \times 10^{10} \mathrm{~m}^{3} \mathrm{a}^{-1}$. To check these calculations, the same set of calculations is made to determine the calving flux at the calving front. In the minimum model, the lower limit of ice thickness and $96 \%$ of the mid-summer velocity are used. This velocity represents the same decrease in percentage from mid-summer velocity as is observed $10 \mathrm{~km}$ behind the calving front. The input data and resultant fluxes are shown in Table II. The minimum calving flux is $3.40 \times$ $10^{10} \mathrm{~m}^{3} \mathrm{a}^{-1}$ and the maximum calving flux is $4.02 \times 10^{10} \mathrm{~m}^{3} \mathrm{a}^{-1}$. Volume flux at the calving front is in good agreement with the volume flux $10 \mathrm{~km}$ behind the calving front. The only difference would be due to the ablation that might occur during the 18 months during which ice moved from the grounding line to the ice front. In this zone, the average melting rate is between 3 and $6 \mathrm{~m} \mathrm{a}^{-1}$ (Braithwaite and Thomsen, 1984; Hughes, 1986). The annual ablation flux is between $0.03 \times 10^{10}$ and $0.06 \times$
$10^{10} \mathrm{~m}^{3} \mathrm{a}^{-1}$. 
TABLE II. THE INPUT VALUES FOR CALCULATION OF THE MINIMUM AND MAXIMUM MASS FLUX OF JAKOBSHAVNS ISBR£ AT THE CALVING FRONT AND $10 \mathrm{~km}$ BEHIND THE CALVING FRONT

\begin{tabular}{lccrr} 
& \multicolumn{2}{c}{ Fjord entrance } & \multicolumn{2}{c}{ Calving front } \\
& Minimum & Maximum & Minimum & Maximum \\
Ice thickness (m) & 750 & 825 & 750 & 810 \\
Center-zone width (m) & 6000 & 6000 & 5250 & 5250 \\
Marginal-zone width (m) & 2600 & 2600 & 4400 & 4400 \\
Center-zone velocity (m/d) & 17.0 & 17.0 & 19.6 & 20.6 \\
Marginal-zone velocity (m/d) & 9.0 & 12.5 & 5.0 & 8.0 \\
Days & 365 & 365 & 365 & 365 \\
$\quad$ Flux $\left(\times 10^{10} \mathrm{~m}^{3} \mathrm{a}^{-1}\right)$ & 3.43 & 4.07 & 3.40 & 4.02
\end{tabular}

\section{SURFACE MASS BALANCE}

To ascertain whether the volume flux into the fjord is in balance with the surface flux of the glacier above the fjord, the mass balance of Jakobshavns Isbra is determined. Bindschadler (1984) gave maximum and minimum estimates of the surface balance for the glacier. Since then, no new accumulation data have been obtained; however, extensive studies have been carried out in the ablation zones of West Greenland outlet glaciers (Braithwaite and Thomsen, 1984; Braithwaite and Olesen, 1985; Braithwaite, 1986; Thomsen and Braithwaite, 1987). No ablation zone was considered in Bindschadler's (1984) calculations. The snow line is at $1450 \mathrm{~m}$; below this point melting averages $1.5 \mathrm{~m}$ of water equivalent (Braithwaite, 1986). There are numerous supraglacial lakes, covering up to $7 \%$ of the glacier surface in July 1985, at altitudes between 1000 and $1450 \mathrm{~m}$. It is not clear how much of this water refreezes and how much is lost from the glacier system. Below $1000 \mathrm{~m}$, there is no mechanism for refreezing most of the melt water generated. During June through August, the mean temperature is $7^{\circ} \mathrm{C}$; resulting melt-water production below $1000 \mathrm{~m}$ exceeds $2.5 \times 10^{9} \mathrm{~m}^{3} \mathrm{a}^{-1}$.

As noted on other West Greenland glaciers, glacier run-off is large. The presence of upwelling fresh water at the calving front is evidence that a large amount of melt water does escape from the glacier system. The upwelling events last for several days and are of a scale indicating outflow of at least $15 \mathrm{~m} / \mathrm{s}$.

Minimum and maximum mass-balance estimates have been made for Jakobshavns Isbræ. The area drained by Jakobshavns Isbræ was identified within certain limits by Bindschadler (1984), using Seasat radar-altimeter data. The velocity vectors obtained by the University of Maine in 1985 and 1986, in the region above the fjord, have further reduced the error in the position of the boundary by better identification of the glacier margin above the fjord entrance. Since surface flow is at right-angles to the surface contours, the effect of a boundary-position change in the lower part of the glacier is transmitted up-glacier. On the basis of the surface-topographic data of Bindschadler (1984), the minimum area boundary of the glacier has been redrawn. It should be noted that there is little change in the maximum boundary position.

The minimum surface-balance calculation assumes that ablation occurs up to the snow line at $1450 \mathrm{~m}$, and that the ablation rate is the same as that on the adjacent Qamanârssûp sermia and Illusiat glaciers (Braithwaite and Oleson, 1985). The maximum surface-balance model assumes that the ablation zone ceases at $1000 \mathrm{~m}$; above this point all melt water is refrozen.

The minimum and maximum surface-balance estimates for Jakobshavns Isbræ (Table III) are $2.87 \times 10^{10}$ to $3.88 \times 10^{10} \mathrm{~m}^{3} \mathrm{a}^{-1}$. The mean value of $3.37 \times 10^{10} \mathrm{~m}^{3} \mathrm{a}^{-1}$ is slightly smaller than the mean volume-flux estimate of $3.72 \times 10^{10} \mathrm{~m}^{3} \mathrm{a}^{-1}$.

\section{CONCLUSIONS}

The terminus of Jakobshavns Isbræ retreated $27 \mathrm{~km}$ between 1850 and 1964 (Carbonnell and Bauer, 1968); this is a rate of $240 \mathrm{~m} / \mathrm{a}$. From 1964 to 1986 , Jakobshavns Isbræ has retreated $1100 \mathrm{~m}$, a rate of $50 \mathrm{~m} / \mathrm{a}$. However, a single calving event of ten results in calving-front retreat of $1000 \mathrm{~m}$. The virtual halt in retreat rate, together with the agreement between surface mass-balance and volume-flux calculations, suggests that Jakobshavns Isbræ is almost in a state of equilibrium.

The fact that the velocity of the glacier increases after it has become afloat indicates there is a force that causes acceleration. This is due to elimination of the basal shear stress as the glacier begins to float and also to the pulling force induced by the imbalance of horizontal gravity forces on floating ice (Lingle and others, 1981; Hughes, 1986). Only calculation of specific stress-strain rates will answer this question fully. However, a reduction in basal shear stress would occur in the north marginal zone of the glacier as well as in the central part, though some side-wall shear remains; yet, there is no velocity increase in this zone. This suggests that a pulling force exists. The fact that the velocity increases from $19.5 \mathrm{~m} / \mathrm{d} 3 \mathrm{~km}$ behind the calving front to $20.6 \mathrm{~m} / \mathrm{d}$ at the calving front, in a region that has been afloat for some time, also supports the idea of a pulling force, which is the dominant force involved in the acceleration (Hughes, 1986).

The fact that there is at most a $7 \%$ decrease in velocity, from the mid-summer velocity to the winter velocity, suggests that there is little annual variation in the basal water pressure. This is in spite of the reduction in actual melt water present.

TABLE III. INPUT VALUES FOR CALCULATION OF MINIMUM AND MAXIMUM SURFACE FLUXES OF JAKOBSHAVNS ISBRÆ ABOVE THE FJORD ENTRANCE

Minimum

$\begin{array}{lrc}\begin{array}{lrc}\text { Altitude } \\ \multicolumn{1}{c}{\mathrm{m}}\end{array} & \begin{array}{r}\text { Area } \\ \mathrm{km}^{2}\end{array} & \begin{array}{c}\text { Net balance } \\ \mathrm{m}\end{array} \\ 0-1000 & 1500 & -1.5 \\ 1000-1400 & 3000 & -0.5 \\ 1400-2500 & 29750 & +0.56 \\ 2500+ & 39750 & +0.40 \\ & & \end{array}$

Total
Mass balance

$\times 10^{6} \mathrm{~m}^{3}$

$-2250$

$-1500$

$+16660$

$+15900$
Maximum

Area Net balance

$\mathrm{km}^{2}$

$\mathrm{m}$

$-1.5$

$+0.25$

$+0.56$

37000
49750

$+0.40$

$+28700 \quad 91900$

Mass balance $\times 10^{6} \mathrm{~m}^{3}$

$+19800$

$+38800$ 


\section{REFERENCES}

Bindschadler, R. A. 1984. Jakobshavns glacier drainage basin: a balance assessment. J. Geophys. Res., 89(C2), 2066-2072.

Braithwaite, R. J. 1986. Assessment of mass balance variations within a sparse stake network, Qamanârssûp sermia, West Greenland. J. Glaciol., 32(110), 50-53.

Braithwaite, R. J. and O.B. Olesen. 1985. Ice ablation in West Greenland in relation to air temperature and global radiation. Z. Gletscherkd. Glazialgeol., 20, 1984, 155-168.

Braithwaite, R.J. and H.H. Thomsen. 1984. Runoff conditions at Kuussuup Tasia, Christianshåb, estimated by modelling. Gronl. Geol. Undersogelse. Gletscher-hydrol. Medd. 84/2.
Brecher, H.H. 1986. Surface velocity determination on large polar glaciers by aerial photogrammetry. Ann. Glaciol., 8, $22-26$.

Carbonnell, M. and A. Bauer. 1968. Exploitation des couvertures photographiques aériennes répétées du front des glaciers vêlant dans Disko Bugt en Umanak Fjord, juin-juillet 1964. Medd. Gronl., 173(5).

Hughes, T.J. 1986. The Jakobshavns effect. Geophys. Res. Lett., 13(1), 46-48.

Lingle, C.S., T.J. Hughes, and R.C. Kollmeyer. 1981. Tidal flexure of Jakobshavns Glacier, West Greenland. $J$. Geophys. Res., 86(B5), 3960-3968.

Thomsen, H.H. and R.J. Braithwaite. 1987. Use of remote-sensing in modelling run-off from the Greenland ice sheet. Ann. Glaciol., 9, 215-217. 